\title{
KAJIAN FAKTOR DEMOGRAFI TERHADAP KEPUASAN PASIEN JAMINAN KESEHATAN NASIONAL PADA FASILITAS KESEHATAN TINGKAT PERTAMA
}

\author{
Putu Dyana Christasani $^{1 *}$, Satibi ${ }^{2}$ \\ ${ }^{1}$ Fakultas Farmasi, Universitas Sanata Dharma, Yogyakarta, Indonesia \\ ${ }^{2}$ Fakultas Farmasi, Universitas Gadjah Mada, Yogyakarta, Indonesia \\ Received April 13, 2016; Accepted April 28, 2016
}

\begin{abstract}
The National Health Insurance (JKN), an Indonesian health care system, has been organized by BPJS Kesehatan using health care assurance mechanism. JKN system gave its service in collaboration with the existing health facilities throughout Indonesia. Primary health facilities named Puskesmas and Klinik Pratama, were playing role as the gate keeper of JKN system in order to provide basic health services optimally. The JKN participants' satisfaction could be used as the indicator for measuring the success rate of the JKN system. The patient demographics was being one of several factor affecting the $J K N$ participants' satisfaction. This study aimed to examine the relationship between patient demographics and JKN participants' satisfaction in Puskesmas and Klinik Pratama located in Sleman, Bantul and Yogyakarta city. This research performed the descriptive analytic using cross sectional survey design. The patients's demographics examined in this study were patients' age, patients' gender, patients' education, patients' employment, patients' income, and membership status. The data taken quantitatively using questionnaires and equipped with qualitative data from interviewing the patients to obtain all the possible findings in the field. Sampling techniques for primary health facilities was performed by random sampling with total sample of 55 health facilities and purposive sampling with a total sample of 150 respondents. Data were analyzed using Chi-Square method to obtain the relationship between patient demographics and JKN participants' satisfaction. The results showed that patient's employment, patient's income, and membership status were significantly related to the JKN participants' satisfaction in Puskesmas and Klinik Pratama.
\end{abstract}

Keywords: patients' demographics, JKN participants' satisfaction, primary health facilities

\section{PENDAHULUAN}

Jaminan Kesehatan Nasional sistem perlindungan kesehatan agar peserta memperoleh manfaat pemeliharaan kesehatan dan perlindungan dalam memenuhi kebutuhan dasar kesehatannya. Pemerintah mengamanatkan bahwa kepesertaan sistem JKN bersifat wajib bagi seluruh penduduk Indonesia dengan tujuan seluruh penduduk dapat memelihara dan memenuhi kebutuhan kesehatannya dengan biaya yang terjangkau (Depkes RI, 2004). Sistem JKN diselenggarakan oleh Badan Penyelenggara Jaminan Sosial (BPJS) Kesehatan, dimana dalam memberikan pelayanannya BPJS Kesehatan bekerjasama dengan fasilitas kesehatan yang ada di seluruh Indonesia (Depkes RI, 2011).

Pada sistem JKN dikembangkan konsep pelayanan berjenjang dengan Fasilitas Kesehatan Tingkat Pertama (FKTP) yaitu Puskesmas, Praktik Dokter, Dokter Gigi, Klinik Pratama atau yang setara, dan Rumah Sakit kelas D atau yang setara sebagai gate keeper. Gatekeeper Concept adalah konsep sistem pelayanan kesehatan dimana FKTP yang berperan sebagai pemberi pelayanan kesehatan dasar dapat berfungsi optimal sesuai standar pelayanan medik dan standar kompetensinya (BPJS Kesehatan, 2014). Bentuk pelayanan berjenjang ini dikenal sebagai sistem rujukan yang menetapkan prosedur rujukan 
sebagai ketentuan yang harus diikuti semua peserta (Andini, 2014).

Terselenggaranya sistem JKN terutama di Fasilitas Kesehatan Tingkat Pertama diharapkan mampu meningkatkan derajat kesehatan seluruh penduduk Indonesia. Oleh karena itu perlu dilakukan monitoring dan evaluasi secara berkala terhadap pelaksanaan sistem JKN. Salah satu indikator yang dapat digunakan untuk mengukur tingkat keberhasilan sistem adalah dengan menilai tingkat kepuasaan pasien peserta JKN. Kepuasan pasien terhadap sistem JKN akan mempengaruhi kelangsungan dan efektivitas sistem JKN yang telah berjalan (Pohan, 2007).

Kepuasan peserta dipengaruhi oleh beberapa aspek, salah satunya adalah faktor demografi pasien. Menurut Schoenfelder dkk. (2010) faktor demografi yang berhubungan signifikan pada kepuasan pasien antara lain umur, jenis kelamin, status sosial, pendidikan, dimana umur dan pendidikan memiliki hubungan yang kuat dengan kepuasan pasien. Menurut penelitian Montol dkk. (2014) dan Stefan dkk. (2014), demografi pasien yaitu pendidikan dan penghasilan memiliki hubungan yang bermakna dengan kepuasan pasien saat menerima pelayanan di Puskesmas.

Tujuan dari penelitian ini adalah untuk menganalisis hubungan antara demografi pasien terhadap kepuasan pasien pada sistem JKN yang dilaksanakan di Puskesmas dan Klinik Pratama yang bekerjasama dengan BPJS Kesehatan. Studi dilakukan pada pasien rawat jalan di Puskesmas dan Klinik Pratama di Kabupaten Sleman, Kabupaten Bantul dan Kota Yogyakarta. Dengan dilakukannya penelitian ini diharapkan dapat memberikan masukan kepada Pemerintah, fasilitas kesehatan, dan BPJS Kesehatan untuk dapat terus memberikan pelayanan kesehatan yang lebih baik kepada masyarakat dan meningkatkan sistem JKN yang telah ada.

\section{METODE PENELITIAN \\ Rancangan Penelitian}

Penelitian ini merupakan penelitian deskriptif analitik yang dilakukan dengan desain cross sectional survey. Data diambil secara kuantitatif dengan menggunakan kuisioner. Responden diminta untuk mengisi kuisioner yang diberikan kemudian dilengkapi dengan data kualitatif melalui wawancara untuk memperdalam temuan di lapangan dan menghasilkan pemahaman yang komprehensif mengenai fenomena yang diteliti di lapangan.

\section{Lokasi dan Sampel Penelitian}

Penelitian dilakukan di FKTP yaitu Puskesmas dan Klinik Pratama di Kabupaten Sleman, Kabupaten Bantul, dan Kota Yogyakarta. Sampel lokasi penelitian ditentukan dengan metode random sampling dan diperoleh sebanyak 55 FKTP yang terdiri dari 40 Puskesmas dan 15 Klinik Pratama. Jumlah sampel responden ditentukan dengan metode purposive sampling dan diperoleh 150 responden. Responden yang diambil sebagai sampel dibagi secara proporsional pada masing-masing FKTP yang terpilih.

Kriteria inklusi dalam penelitian ini, yaitu : pasien merupakan pasien rawat jalan di FKTP (Puskesmas dan Klinik Pratama) di Kabupaten Sleman, Kabupaten Bantul, dan Kota Yogyakarta yang berumur diatas 18 tahun; pasien merupakan peserta JKN dan tidak menjadi peserta jaminan sosial kesehatan yang lain; pasien bersedia berpartisipasi dalam penelitian ini dengan mengisi kuisioner yang diberikan; pasien kooperatif dan dapat berkomunikasi dengan baik; dan telah melakukan kunjungan minimal 2 kali ke FKTP yang sama sejak diberlakukannya sistem JKN.

\section{Instrumen Penelitian}

Instrumen penelitian yang digunakan adalah kuisioner yang memuat pertanyaan mengenai demografi pasien, pernyataan dengan jawaban terstruktur menyangkut kepuasan pasienterhadap sistem JKN di FKTP, dan yang terakhir adalah pertanyaan terbuka mengenai keluhan dan saran pasien. Pernyataan dalam kuisioner disusun berdasarkan peraturan perundang-undangan yang berlaku dan panduan praktis terkait sistem JKN yang diterbitkan oleh BPJS Kesehatan. Kuisioner mengenai kepuasan pasien di uji validitasnya dengan metode Product Moment Pearson dengan kriteria valid bila $\mathrm{r}$ hitung $>0,361$ dan uji reliabilitas dengan metode Cronbach's Alpha dengan kriteria reliabel bila nilai Cronbach's Alpha $>0,6$. Dari 10 item pernyataan mengenai 
kepuasan pasien terhadap sistem JKN sebanyak 3 item pertanyaan dinyatakan tidak valid sehingga dihilangkan dari kuisioner.

Diakhir kuisiner terdapat tiga pertanyaan terbuka mengenai kepuasan pasien, kesan atau pengalaman selama menjadi peserta JKN, serta saran yang diberikan untuk perbaikan sistem JKN. Ketiga pertanyaan terbuka tersebut kemudian dikembangkan dalam bentuk wawancara singkat dengan pasien untuk memperdalam setiap fakta yang ditemukan di lapangan. Wawancara dilakukan terhadap seluruh responden yang mengisi kuisioner.

\section{Analisis Data}

Analisis univariat digunakan untuk menggambarkan keseluruhan demografi sampel penelitian, yang terdiri dari: umur, jenis kelamin, pendidikan, pekerjaan, pendapatan, dan status kepesertaan. Kemudian dilanjutkan dengan analisis bivariat untuk mengetahui adanya hubungan antara masing-masing kelompok demografi pasien dengan kepuasan pasien menggunakan Uji Chi-Square, dimana dianggap memiliki hubungan yang signifikan bila nilai $\mathrm{p}<0,05$. Data untuk hasil wawancara di analisis secara kualitatif untuk menambah informasi terkait tentang variabel-variabel yang berhubungan dengan kepuasan pasien.

\section{HASIL DAN PEMBAHASAN}

\section{Analisis Univariat Demografi Pasien}

Penelitian ini menggunakan responden sebanyak 150 pasien rawat jalan di Puskesmas dan Klinik Pratama di Kabupaten Sleman, Kabupaten Bantul dan Kota Yogyakarta.

Tabel I. Karakteristik Pasien

\begin{tabular}{|c|c|c|c|c|}
\hline \multirow{2}{*}{ No } & \multirow{2}{*}{$\begin{array}{l}\text { Penggolongan } \\
\text { Demografi }\end{array}$} & \multirow{2}{*}{ Parameter } & \multicolumn{2}{|c|}{ Responden } \\
\hline & & & $\mathrm{n}$ & $\%$ \\
\hline \multirow{4}{*}{1.} & \multirow{4}{*}{ Usia } & 18-32 tahun & 28 & 18,67 \\
\hline & & 33-47 tahun & 39 & 26,00 \\
\hline & & 48-62 tahun & 51 & 34,00 \\
\hline & & Lebih dari 62 tahun & 32 & 21,33 \\
\hline \multirow{2}{*}{2.} & \multirow{2}{*}{ Jenis kelamin } & Laki-laki & 68 & 45,33 \\
\hline & & Perempuan & 82 & 54,67 \\
\hline \multirow{5}{*}{3.} & \multirow{5}{*}{ Pendidikan } & SD & 15 & 10,00 \\
\hline & & SMP & 31 & 20,67 \\
\hline & & SMA & 52 & 34,67 \\
\hline & & Diploma/sarjana & 41 & 27,33 \\
\hline & & Pascasarjana & 11 & 7,33 \\
\hline \multirow{6}{*}{4.} & \multirow{6}{*}{ Pekerjaan } & Pelajar/mahasiswa & 15 & 10,00 \\
\hline & & Wiraswasta & 33 & 22,00 \\
\hline & & PNS & 22 & 14,67 \\
\hline & & Pensiunan & 23 & 15,33 \\
\hline & & Pegawai swasta & 29 & 19,33 \\
\hline & & Tidak bekerja & 28 & 18,67 \\
\hline \multirow{5}{*}{5.} & \multirow{5}{*}{ Pendapatan } & Kurang dari 1 juta & 27 & 18,00 \\
\hline & & $1-2$ juta & 45 & 30,00 \\
\hline & & 2-3 juta & 35 & 23,33 \\
\hline & & $3-4$ juta & 26 & 17,33 \\
\hline & & Lebih dari 4 juta & 17 & 11,33 \\
\hline \multirow{3}{*}{6.} & \multirow{3}{*}{$\begin{array}{c}\text { Status } \\
\text { kepesertaan }\end{array}$} & Penerima bantuan iuran & 43 & 28,67 \\
\hline & & Pekerja penerima upah & 59 & 39,33 \\
\hline & & Pekerja bukan penerima upah & 48 & 32,00 \\
\hline
\end{tabular}


Tabel II. Hubungan Demografi dengan Kepuasan Pasien

\begin{tabular}{|c|c|c|c|c|c|}
\hline \multirow{2}{*}{$\begin{array}{c}\text { Penggolongan } \\
\text { Demografi }\end{array}$} & \multirow{2}{*}{ Parameter } & \multicolumn{2}{|c|}{ Kepuasan Pasien } & \multirow{2}{*}{ Total } & \multirow{2}{*}{$p$ value } \\
\hline & & Puas & Tidak Puas & & \\
\hline \multirow{5}{*}{ Usia } & 18-32 tahun & 22 & 6 & 28 & \multirow{5}{*}{0,650} \\
\hline & 33-47 tahun & 25 & 14 & 39 & \\
\hline & 48-62 tahun & 35 & 16 & 51 & \\
\hline & Lebih dari 62 tahun & 22 & 10 & 32 & \\
\hline & Total & 104 & 46 & 150 & \\
\hline \multirow{3}{*}{ Jenis kelamin } & Laki-laki & 46 & 22 & 68 & \multirow{3}{*}{0,683} \\
\hline & Perempuan & 58 & 24 & 82 & \\
\hline & Total & 104 & 46 & 150 & \\
\hline \multirow{6}{*}{ Pendidikan } & SD & 11 & 4 & 15 & \multirow{6}{*}{0,951} \\
\hline & SMP & 22 & 9 & 31 & \\
\hline & SMA & 37 & 15 & 52 & \\
\hline & Diploma/sarjana & 26 & 15 & 41 & \\
\hline & Pascasarjana & 8 & 3 & 11 & \\
\hline & Total & 104 & 46 & 150 & \\
\hline \multirow{7}{*}{ Pekerjaan } & Pelajar/mahasiswa & 11 & 4 & 15 & \multirow{7}{*}{0,000} \\
\hline & Wiraswasta & 24 & 9 & 33 & \\
\hline & PNS & 5 & 17 & 22 & \\
\hline & Pensiunan & 17 & 6 & 23 & \\
\hline & Pegawai swasta & 22 & 7 & 29 & \\
\hline & Tidak bekerja & 25 & 3 & 28 & \\
\hline & Total & 104 & 46 & 150 & \\
\hline \multirow{6}{*}{ Pendapatan } & Kurang dari 1 juta & 27 & 0 & 27 & \multirow{6}{*}{0,000} \\
\hline & 1-2 juta & 32 & 13 & 45 & \\
\hline & $2-3$ juta & 26 & 9 & 35 & \\
\hline & $3-4$ juta & 11 & 15 & 26 & \\
\hline & Lebih dari 4 juta & 8 & 9 & 17 & \\
\hline & Total & 104 & 46 & 150 & \\
\hline \multirow{4}{*}{$\begin{array}{c}\text { Status } \\
\text { kepesertaan }\end{array}$} & Penerima bantuan iuran & 40 & 3 & 43 & \multirow{4}{*}{0,000} \\
\hline & Pekerja penerima upah & 36 & 23 & 59 & \\
\hline & Pekerja bukan penerima upah & 28 & 20 & 48 & \\
\hline & Total & 104 & 46 & 150 & \\
\hline
\end{tabular}

Hasil analisis univariat (Tabel I) menunjukkan bahwa demografi pasien sebagian besar berusia 4862 tahun (34\%). Data-data tersebut menunjukkan bahwa sebagian besar peserta BPJS Kesehatan yang menggunakan layanan kesehatan adalah kelompok usia dewasa dan lanjut. Semakin tua umur responden kecenderungan untuk lebih sering memanfaatkan pelayanan kesehatan akan lebih tinggi (Sumaryanti, 2000). Responden dengan jenis kelamin wanita lebih banyak daripada laki-laki, yaitu sebesar 54,67\%. Menurut survei nasional di Amerika Serikat menunjukkan sebuah kesimpulan bahwa wanita memiliki peran yang penting sebagai penentu keputusan dalam pelayanan kesehatan, tidak hanya bagi dirinya sendiri tetapi juga bagi keluarganya (Kotler dkk., 2008).

Karakteristik pendidikan terakhir responden yang memiliki proporsi terbanyak adalah SMA dengan persentase $34,67 \%$ dan Diploma/Sarjana dengan persentase $27,33 \%$. Tingkat pendidikan yang semakin tinggi memudahkan seseorang untuk mengolah informasi yang diterima menjadi suatu sikap tertentu, termasuk pula dalam pemeliharaan kesehatannya (Notoatmodjo, 2010). Karakteristik pekerjaan responden terbanyak adalah wiraswasta yaitu responden yang bekerja sebagai pedagang, montir, tukang becak, dan pekerjaan lain yang dimiliki sendiri oleh responden, dengan persentase 22\%. Menurut Badan Pusat Statistik Povinsi DI Yogyakarta pada tahun 2014, jumlah tenaga kerja yang bekerja pada kegiatan informal di DI Yogyakarta lebih besar daripada jumlah tenaga kerja yang bekerja pada kegiatan formal dengan persentase sebesar 54,09\%. Maka responden yang diperoleh dalam penelitian sebagian besar 
memiliki pekerjaan dari sektor informal yaitu wiraswasta.

Selanjutnya pada data pendapatan dapat dilihat bahwa peringkat pertama sebesar $30 \%$ adalah kelompok responden yang memiliki pendapatan 1-2 juta per bulan. Upah Minimum Kabupaten/Kota untuk Yogyakarta tahun 2014 ratarata sebesar 1,1 juta rupiah per bulan dan sebagian besar responden pada penelitian ini memiliki pekerjaan sebagai wiraswasta (pedagang kecil, tukang becak, usaha kerajinan), petani, dan ibu rumah tangga sehingga pendapatan yang diperoleh tidak terlalu tinggi. Pada data status kepesertaan persentase terbanyak yaitu $39,33 \%$ merupakan pekerja penerima upah karena untuk PNS dan pensiunan langsung secara otomatis terdaftar sebagai peserta JKN dan sebagian besar perusahaan swasta sudah mengalihkan jaminan kesehatan untuk karyawannya ke BPJS. Menurut data BPJS Kesehatan (2014) jumlah PNS/Pensiunan yang sudah terdaftar sebagai peserta BPJS sebanyak 390,346 jiwa dan jumlah peserta yang didaftarkan melalui badan usaha/perusahaan sebanyak 149,194 jiwa. Walaupun jumlah peserta tersebut lebih kecil dari jumlah peserta penerima bantuan iuran (jamkesmas) namun keinginan dan kemampuan pekerja penerima upah untuk mengakses pelayanan kesehatan lebih tinggi.

\section{Analisis Bivariat Hubungan Demografi Pasien Terhadap Kepuasan Pasien}

Analisis ini digunakan untuk membuktikan ada tidaknya hubungan antara demografi pasien terhadap kepuasan pasien di FKTP terkait pelaksanaan sistem JKN (Tabel II). Data dianalisis menggunakan uji Chi-Square/Chi kuadrat dengan batas nilai signifikansi $\mathrm{p}<0,05$.

Pada analisis hubungan perbedaan usia dengan kepuasan pasien diperoleh bahwa baik usia muda hingga usia tua cenderung merasa puas dengan pelayanan yang diberikan pada sistem JKN dengan nilai $p=0,650(p>0,05)$. Hal ini berarti tidak terdapat hubungan yang signifikan antara tingkat usia dan kepuasan pasien. Menurut Manurung (2010) dan Bauk dkk. (2013), tidak terdapat hubungan yang signifikan antara tingkat usia dan kepuasan pasien. Semua usia baik muda maupun tua merasa puas dengan sistem JKN yang telah berjalan, walaupun terdapat kecenderungan pasien dengan usia lebih tua cenderung merasa puas terhadap pelayanan yang diberikan. Sesuai hasil wawancara yang dilakukan, semua kelompok usia merasa puas terhadap pelayanan pada sistem JKN. Pasien dengan usia lebih muda walaupun menyatakan secara keseluruhan merasa puas terhadap sistem JKN namun tetap menyampaikan keluhan dan saran untuk perbaikan sistem.

Pada analisis hubungan perbedaan jenis kelamin dengan kepuasan pasien diperoleh hasil bahwa tidak terdapat hubungan perbedaan jenis kelamin terhadap kepuasan yang ditunjukkan dengan nilai $\mathrm{p}=0,683(\mathrm{p}>0,05)$. Menurut penelitian Anjaryani (2009), baik laki-laki maupun perempuan cenderung memiliki tingkat kepuasan yang sama saat menerima pelayanan kesehatan. Berdasarkan hasil wawancara, responden dengan jenis kelamin perempuan lebih mudah menyampaikan keluhan dibanding dengan lakilaki. Sebagian besar responden wanita merupakan ibu-ibu yang memiliki peran penting sebagai penentu keputusan dalam pelayanan kesehatan, tidak hanya bagi dirinya sendiri tetapi juga bagi keluarganya (Manurung, 2010).

Pada analisis hubungan perbedaan pendidikan dengan kepuasan pasien diperoleh bahwa tidak terdapat hubungan perbedaan pendidikan terhadap kepuasan pasien yang ditunjukkan dengan nilai $\mathrm{p}=0,951$ ( $\mathrm{p}>0,05)$. Menurut penelitian Manurung (2010) dan Sudarni (2009) tidak terdapat hubungan antara pendidikan dengan kepuasan pasien dalam menerima pelayanan kesehatan. Setiap perilaku salah satunya perilaku puas juga dipengaruhi oleh kecerdasan atau pengetahuan yang dimiliki oleh pasien selain tingkat pendidikannya (Bauk dkk, 2013). Dari hasil wawancara dengan pasien, sebagian besar tanggapan tentang kepuasan, keluhan, dan saran muncul dari pasien dengan pendidikan yang lebih tinggi. Namun hal tersebut tidak terlalu berpengaruh signifikan karena pada semua kategori pendidikan, sebagian besar pasien menyatakan bahwa mereka puas dengan sistem JKN.

Pada analisis hubungan perbedaan pekerjaan dengan kepuasan pasien diperoleh bahwa rata-rata pelajar/mahasiswa, wiraswasta, pensiunan, pegawai swasta, maupun responden yang tidak bekerja cenderung puas dengan pelayanan JKN. Maka disimpulkan bahwa terdapat hubungan yang signifikan antara perbedaan pekerjaan dengan 
kepuasan pasien dengan nilai $\mathrm{p}=0,000 \quad(\mathrm{p}<0,05)$. Responden dengan pekerjaan menengah ke bawah cenderung puas dengan sistem pelayanan di fasilitas kesehatan (Ulfa, 2012). Berdasarkan hasil wawancara, sebagian besar responden dengan pekerjaan sebagai PNS menyatakan tidak puas dengan sistem JKN yang berjalan. Hal ini disebabkan karena terdapat perbedaan antara sistem pelayanan pada saat menjadi peserta Askes dengan menjadi peserta JKN. Penyesuaian ini menyebabkan responden yang bekerja sebagai PNS merasa tidak puas dengan sistem yang berjalan.

Pada analisis hubungan perbedaan pendapatan dengan kepuasan pasien diperoleh bahwa sebagian besar responden dengan pendapatan kecil ( $<1$ juta) sampai pendapatan sedang (2-3 juta) merasa puas dengan pelayanan JKN. Namun beberapa responden dengan pendapatan tinggi (>3 juta) menyatakan tidak puas dengan pelayanan JKN yang diberikan. Dari hasil analisis diketahui bahwa terdapat hubungan yang signifikan antara pendapatan dengan kepuasan pasien dengan nilai $\mathrm{p}=0,000$ $(\mathrm{p}<0,05)$. Menurut Hidayati dkk. (2014) semakin tinggi pendapatan pasien maka semakin tinggi pula tuntutan pasien terhadap pelayanan kesehatan dan sistem JKN yang sedang berjalan. Menurut Barata (2006), pendapatan pasien menentukan kepuasan yang dirasakan karena jika pendapatan yang diperoleh kecil maka pelayanan kesehatan yang diperoleh cenderung lebih sedikit atau minimal.

Pada analisis hubungan perbedaan status kepesertaan dengan kepuasan pasien diketahui bahwa terdapat hubungan yang signifikan antara status kepesertaan dengan kepuasan dengan nilai $\mathrm{p}=0,000 \quad(\mathrm{p}<0,05)$. Menurut Budiman dkk. (2010) terdapat perbedaan kepuasan antara pasien yang iurannya dibayar secara mandiri, dengan yang dibayarkan oleh Pemerintah maupun instansi tempat kerja. Responden yang iurannya dibayarkan oleh Pemerintah cenderung merasa puas dengan sistem yang ada karena tanpa membayar iuran apapun mereka dapat memperoleh pelayanan kesehatan. Dari hasil wawancara diperoleh informasi bahwa responden yang iurannya dibayarkan oleh Pemerintah cenderung merasa puas dengan sistem yang ada. Keluhan dan pernyataan tidak puas banyak muncul dari pekerja penerima upah dan responden yang iurannya dibayar secara mandiri karena beberapa prosedur kepesertaan yang dirasa rumit dan kurangnya sosialisasi mengenai sistem
JKN yang sedang berjalan. Selain itu karena responden merasa telah memenuhi kewajibannya dengan membayar iuran setiap bulan maka harapan terhadap pelayanan kesehatan yang lebih baik menjadi lebih tinggi.

\section{KESIMPULAN}

Berdasarkan hasil penelitian diketahui bahwa demografi pasien merupakan faktor yang berhubungan secara bermakna terhadap kepuasan pasien pada sistem JKN di Puskesmas dan Klinik Pratama. Perbedaan karakteristik pasien dalam hal pekerjaan, pendapatan, dan status kepesertaan memiliki hubungan yang signifikan terhadap kepuasan pasien pada sistem JKN.

\section{DAFTAR PUSTAKA}

Andini, U.F., 2014. Hak Perawatan Pegawai Negeri Sipil : Implementasi Pasal 9 Ayat (1) Undang-Undang No. 43 Tahun 1999 Studi Di PT Askes (Persero) Malang Dan Rumah Sakit Umum Saiful Anwar Malang. Jurnal Mahasiswa Fakultas Hukum, 1.

Anjaryani, W.D., 2009. Kepuasan Pasien Rawap Inap Terhadap Pelayanan Perawat Di RSUD Tugurejo Semarang, Tesis, MSc, Magister Promosi Kesehatan, Universitas Diponegoro, Semarang.

Badan Pusat Statistik DIY, 2014. Berita Resmi Statistik : Keadaan Ketenagakerjaan Di D.I. Yogyakarta Tahun 2014. Berita Resmi Statistik Badan Pusat Statistik Provinsi D.I Yogyakarta, No.29/05/34/Th.XVI.

Barata, A. A., 2006. Dasar-Dasar Pelayanan Prima. PT Elex Media Komputindo, Jakarta.

Bauk, I., Kadir, A.R., dan Saleh, A., 2013. Hubungan Karakteristik Pasien Dengan Kualitas Pelayanan: Persepsi Pasien Pelayanan Rawat Inap RSUD Majene Tahun 2013. Jurnal Passcasarjana Universitas Hasanuddin, -.

BPJS Kesehatan, 2014. Menyongsong Jaminan Kesehatan Semesta Di Daerah Istimewa Yogyakarta Bersama BPJS Kesehatan. BPJS Kesehatan Provinsi Daerah Istimewa Yogyakarta, -.

Budiman, Suhat, dan Herlina, N., 2010. Hubungan Status Demografi Dengan Kepuasan Masyarakat Tentang Pelayanan Jamkesmas 
Di Wilayah Puskesmas Tanjungsari Kabupaten Bogor Tahun 2010. Jurnal Kesehatan Kartika, 27: -.

Depkes RI, 2004. Undang-Undang Republik Indonesia Nomor 40 Tahun 2004 Tentang Sistem Jaminan Sosial Nasional. Kementrian Kesehatan Republik Indonesia, Jakarta.

Depkes RI, 2011. Undang-Undang Republik Indonesia, Nomor 24 Tahun 2011, Tentang Badan Penyelenggara Jaminan Sosial. Sekretariat Negara Republik Indonesia, Jakarta.

Hidayati, A.N., Suryawati, C., dan Sriatmi, A., 2014. Analisis Hubungan Karakteristik Pasien dengan Kepuasan Pelayanan Rawat Jalan Semarang Eye Center (SEC) Rumah Sakit Islam Sultan Agung Semarang. Jurnal Kesehatan Masyarakat, Volume 2, Nomor 1, Januari 2014.

Kotler, P., Shalowitz, J., dan Stevens, R., 2008. Strategic Marketing for Health Care Organizations: Building A CustomerDriven Health System. Jossey-Bass, San Francisco.

Manurung, L.P., 2010. Analisis Hubungan Tingkat Kepuasan Pasien Rawat Jalan Terhadap Pelayanan Instalasi Farmasi Dengan Minat Pasien Menebus Kembali Resep Obat Di Instalasi Farmasi RSUD Budhi Asih Tahun 2010, Tesis, MPH, Fakultas Kesehatan Masyarakat, Universitas Indonesia, Jakarta.

Montol, S.A., Maramis, F.R., dan Engkeng, S., 2014. Hubungan Antara Status Demografi Dengan Kepuasan Dalam Pelayanan Pasien Jamkesmas Di Wilayah Kerja Puskesmas Ratahan Kabupaten Minahasa Tenggara, Skripsi, Fakultas Kesehatan Masyarakat, Universitas Sam Ratulangi, Manado.
Notoatmodjo, S., 2010. Ilmu Perilaku Kesehatan. Rineka Cipta, Jakarta.

Pohan, I.S., 2007. Jaminan Mutu Pelayanan Kesehatan Dasar-Dasar Pengertian Dan Penerapan. Penerbit Buku Kedokteran EGC, Jakarta.

Schoenfelder, T., Klewer, J., dan Kugler, J., 2010. Factors Associated with Patient Satisfaction in Surgery: The Role of Patients' Perceptions of Received Care, Visit Characteristics, and Demographic Variables. Journal of Surgical Research, 164: 53-59.

Stefan, M.M., REdjeki, S.G., dan Susilo, H.W., 2014, Hubungan Karakteristik Pasien Dengan Kepuasan Pasien Terhadap Mutu Pelayanan Kesehatan Di Puskesmas Kecamatan Pesanggrahan Jakarta Selatan 2013, Bagian Penelitian STIK Sint Carolus.

Sudarni, D., 2009. Hubungan Karakteristik Pasien Dengan Kepuasan Terhadap Mutu Pelayanan Rawat Inap Di Badan Rumah Sakit Umum Daerah Waled Kabupaten Cirebon Tahun 2009, Tesis, MPh, Fakultas Kesehatan Masyarakat, Universitas Indonesia, Jakarta.

Sumaryanti, S., 2000. Pemanfaatan Pelayanan Kesehatan Oleh Masyarakat di Puskesmas Di Kecamatan Selogiri Kabupaten Wonogiri. Jurnal Media Medika Muda, 131.

Ulfa, R., 2012. Hubungan Karakteristik Pasien, Kualitas Layanan dan Hambatan Pindah dengan Loyalitas Pasien di Instalasi Rawat Jalan Rumah Sakit Tugu Ibu Depok Tahun 2011, Tesis, MSc., Fakultas Kesehatan Masyarakat, Universitas Indonesia, Jakarta. 